\author{
Kelemen-Hényel Nikoletta
}

\title{
Az európai építőipari mikrovállalkozások árbevételének hatása az európai uniós tagországok makrogazdasági mutatóira
}

\section{The Impact of the Sales Revenues of European Construction Micro-enterprises on the Macroeconomic Indicators of the Member States of the European Union}

\section{ÖSSZEFOGLALÁS}

Az európai vállalkozások meghatározó része a KKV-k csoportjába tartozik, emiatt szerepük kiemelkedően fontos a nemzetgazdaságban. Az építőipari KKV-k jelentősége megkérdőjelezhetetlen az Európai Unióban. A szektor a GDP közel 10\%-át állítja elő és hozzávetőlegesen 42,9 millió munkahely teremtését garantálja. A kutatásomban azt vizsgálom, hogy milyen direkt, illetve indirekt hatások mutathatóak ki az építőipari KKV-k árbevétele és a makrogazda- sági mutatók között, ha abból a feltételezésből indulok ki, hogy a megtakarítások direkt hatása az építőipari mikrovállalkozások árbevételén keresztül, további indirekt hatásokat fejtenek ki a GDP-re, a munkanélküliségi rátára, valamint az inflációra. A kutatás eredményeként fő megállapításom, hogy az építőipari mikrovállakozások árbevételének pozitív hatása az elmaradott európai tagországoknál jelentősebb volt.

Journal of Economic Literature (JEL) kódok: A10, A19, P43, H20

Kelemen-Hényel Nikoletta, PhD hallgató, Magyar Agrár- és Élettudományi Egyetem, Gazdaság- és Regionális Tudományi Doktori Iskola (henyel@ henyel-kelemen.de). 
Kulcsszavak: Európai Unió tagországok, árbevétel, építőipar, makrogazdasági mutatók, mikrovállalkozások

\section{Summary}

The decisive majority of the European enterprises are SMEs; therefore, SMEs have a prominent role within the national economy. Without doubt, construction SMEs are very important within the European Union. This sector produces nearly 10 percent of the GDP of the EU and guarantees the creation of some 42.9 million jobs. In my research, I examined the direct and indirect impacts that may be shown between the sales revenue of the construction SMEs and the macro-economic indices, if we assume that the direct impact of savings exerts further indirect impacts on the GDP, the unemployment rate and the inflation through the sales revenues of the construction micro-enterprises. The main finding of my research was that the sales revenue of the construction micro-enterprises had a more significant positive impact in less developed European Members States.

Journal of Economic Literature (JEL) codes: A10, A19, P43, H20

Keywords: Member States of the European Union, sales revenue, construction industry, macro-economic indices, micro-enterprises

\section{BevezetéS}

A kis- és közepes vállalkozások szerepe kiemelkedően fontos a piacgazdaságban. A KKV-k hatása az európai gazdaságra megkérdőjelezhetetlen, hiszen ez a szektor adja a munkahelyek több, mint 90\%-át az EU tagországokban (Európai Parlament, 2021). Az építőipari szektor jelentős szerepet játszik a tagországok jövedelemtermelésében, a külföldi tőke áramlásában, a beruházásokban és a munkahelyteremtésben is. A vállalkozások a mindennapi tevékenységükkel hozzájárulnak a jóléti társadalom működéséhez, gyarapodásához. A KKV-k gazdasági szerepe felértékelődött az elmúlt 30 évben, elsősorban azáltal, hogy a nagy- vállalatok az értékláncok mentén a tevékenységeik jelentős részét kiszervezték. A világ hamar ráébredt arra, hogy a KKV-szektor fejlesztése elengedhetetlen, így Japán és Amerika után az Európai Unió is lépéseket tett a KKV-szektor fejlesztésére. Az Európai Unió már a 2000-es évektől kiemelt figyelmet fordított a KKV-k vállalkozási képességeinek és a támogató keretrendszerének megerősítésére.

\section{SZAKIRODALMI ÁTTEKINTÉS}

A KKV-k szerepe igen fontos mind a gazdasági növekedés, mind a munkahelyteremtés előmozdítása, de a társadalom fejlődése szempontjából is (Csath, 2015). Az Európai Unióban a KKV-k száma az összes vállalkozás közel 99\%-át teszi ki, így értelemszerűen szoros kapcsolatban áll a munkahelyek számával, ami eléri az összes foglalkoztatottak kétharmadát a magánszektorban (Eurostat Yearbook, 2010). Az építőipari KKV-k jelentősége megkérdőjelezhetetlen az Európai Unióban. Az építőipari szektor a GDP közel 10\%-át állítja elő (Losoncz, 2019) és közel 42,9 millió munkavállaló közvetlenül vagy közvetve függ az építőipari szektortól (IW, 2020). Az Európai Bizottság által készített több jelentés is megállapítja, hogy az építőipari szektor teljesítménye nagymértékben meghatározza a teljes gazdaság alakulását." (Bizottság, 2012),( European Commission, 2015a).

Barsi (2002) munkájában hivatkozik egy további jelentésre - SECTEUR -, amely szerint az Európai Unió beruházásainak több mint a fele építőiparinak tekinthető és az építőipar az egyetlen olyan szektor, ahol minden egyes új munkahely további két munkahelyet teremt más ágazatokban. Közel 2 millió építőipari vállalkozás működik aktívan az Európai Unióban, amelynek 92\%-a mikrovállalkozásnak minősül. A mikrovállalkozások főbb problémája közé tartozik, hogy tőkeellátottságuk és likviditásuk (Barsi, 2002), valamint az innovációs képességük nagyon alacsony (Bencsik - Filep, 2020).

A szektor az egyik legérzékenyebb ágazatok közé tartozik, amelyet súlyosan érintett a 2008ban kitört pénzügyi világválság (Vasa, 2010; 
Lentner et al., 2020). A beruházási kedv 2011 ben a 2009-es adatokhoz viszonyítva 16\%-os visszaesését mutatott. A válság országonként eltérő hatást váltott ki: míg a közép-európai országokban - mint Magyarország és Románia - az ingatlanárak hirtelen csökkenése okozott drámai visszaesést az építőiparban, addig más országokban a hitelpiac bedőlése eredményezte az építőipari teljesítmény zsugorodását (Európai Bizottság, 2012; European Commission, 2015a; European Commission,2015b; Bite et al., 2020).

Lengyel és Rechnitzer 2002-ben részletesen elemezte az EU tagság várható hatásait a KKV-szektorra vonatkozóan. Mivel a magyar vállalkozásokat a közös piacra való lépés egy teljesen új helyzet elé állította, véleményük szerint a kisvállalkozások fogják leginkább megszenvedni - a csak jelentős befektetésekkel végrehajtható - a követelményeknek való megfelelést. Annak ellenére, hogy az építőipar szerepe a magyar nemzetgazdaságban megkérdőjelezhetetlen, a szektor nem tudta elérni, hogy egy stabil hátérrel rendelkező intézményesültséget hozzanak létre (Lengyel-Rechnitzer, 2002). Lengyel és Rechnitzer arra az álláspotra jutottak, hogy az építőipari vállalkozások versenyképességének a kulcsa a vállalati együttműködésben, a hálózatosodásban és a klaszeteresedésben rejlik.

Bajmóczi (2002) szerint az építőipari ágazaton belül a 2000-es évek elején egyáltalán nem volt jellemző a vállalkozások együttműködése, amely nehezítette a klaszterek kialakulását. Egyes kutatók szerint azonban a vállalkozások a specializálódást túl kockázatosnak tartják. A dán gazdaságban az építőipari szektor komoly jelentőséggel bír, emiatt nagy hangsúlyt fektetnek a szektor versenyképességének növelésére. Emiatt a dán kormány már 1999-től különböző intézkedésekkel segítette az építőipari szektort (Danisch Goverment, 1999). A dán kormány felhagyott a szétaprózott iparági programokkal és helyette iparágcsoportokra koncentráló intézkedéscsomagokkal próbálta a versenyképességet erősíteni. Rájöttek, hogy a fejlődés inkább a vállalkozások, szektorok, piacok és intézmé- nyek közötti kapcsolatokban rejlik (Bajmóczi et al., 2002). A dán gazdaság versenyképességének növekedése érdekében 2000 és 2001 között a következő célokat fogalmazták meg (Bajmóczi et al., 2002):

- az építőipari vállalkozások közötti együttműködés erősítése,

- folyamatos információáramlás az építőipari vállalkozások helyzetéről és teljesítményéről,

- az iparosodottság fokának növelése,

- az építőipari munka minőségének növelése,

- a kutatás és fejlesztés előtérbe helyezése.

Ezeket figyelembe véve Buzás (2002) és kutatótársai a magyar építőipar klaszterének lehetséges fejlesztési stratégiáira tettek javaslatot. Véleményük szerint nem létezik egy bevált klaszter-sablon, mely minden egyes országban működne. Álláspontjuk szerint klaszter-fejlesztés van, amely révén a klasztert a kormányzati és a magánszervezetek sajátosságaihoz, valamint folyamatos változásaihoz alakítják (Buzás et al., 2002). Az általános klaszterfejlesztésnél mérvadó OECD irányelvei (OECD 2001) alapján a következő fontos észrevételeket is figyelembe kell venni a kutatók szerint. Az építőipari klaszter alatt kell érteni minden, az építőiparhoz köthető szolgáltatást. Jelen esetben a tervezéstől kezdve a termelési láncon keresztül az ingatlan ügyekig. Az építőipar meghatározó cégei, amelyek az értéklánc-rendszer végén állnak, elkezdenek egymás stratégiai szövetségeseivé válni. Amikor ez a folyamat nyilvánvalóan körvonalazódik, ekkor szükséges a kormányzati háttértámogatás (Buzás et al., 2002).

\section{KutatÁs MÓdszertana}

\section{Felhasznált adatbázis}

A szekunder kutatás adatbázisát az Európai Unió Statisztikai Hivatala, azaz a EUROSTAT, valamint a Világbank statisztikai adatbázisa szolgáltatták. Az európai építőipari KKV-kat érintő adatsorokat az EUROSTAT oldalán található adatbázisból töltöttem fel. 
A szervezet részletesen publikálta az európai építőipari KKV-k méret szerinti mennyiségét, valamint árbevételét, országokra lebontva. Ennek az adatbázisnak köszönhetően tudtam a mikrovállalkozások kapcsolatát vizsgálni az Európai Unió tagországainak makrogazdasági mutatóival kapcsolatban.

Már a kutatás kezdetén kiderült, hogy az EUROSTAT, valamint a Világbank adatbázisa sok esetben hiányos. Amíg az EUROSTAT oldala a KKV-szektort érintő statisztikai jelentésekben nem bővelkedik, addig a Világbank statisztikai adatai csak 2018-ig érhetőek el. Így a szervezet által publikált adatokból töltöttem fel a kutatás alapjául szolgáló adatbázisomat. A tagországok egyes makrogazdasági mutatóit GDP, infláció, megtakarítás - a Világbank statisztikai oldalán értem el hiánytalanul, 20002018-as időszakra, addig a munkanélküliségi rátát, a megtakarítást és a EU támogatásokat az EUROSTAT (ESA 2010) oldaláról gyűjtöttem be. A két statisztikai oldal által publikált adatok eltérő pénznemben voltak megadva. Így azokat az adattömböket, amelyek dollárban voltak meghatározva, a Világbank által publikált rögzített árfolyamon váltottam át euróra.

\section{Klaszteranalizis}

A vizsgálat során klaszteranalízis elemzést végeztem az Európai Unió 27 tagországra a 2000-2019 közötti időszakra vonatkozóan. A klaszteranalízis egy olyan eljárás, amellyel

\section{1. táblázat: Illeszkedési mutatók ajánlott értéke}

adattömböket tudunk viszonylag homogén csoportokba sorolni, azaz klasszifikálni. Célom az volt, hogy olyan csoportokat hozzak létre, amelyek jobban hasonlítanak egymáshoz, mint más csoport tagjaihoz. Makrogazdasági mutatókból származó adattömböket próbáltam homogén csoportokba sorolni. Vizsgálataim során a hierarchikus Ward módszert alkalmaztam (Jánosa, 2015 alapján). A Ward-kritérium, egy olyan módszer, amelynél arra törekszünk, hogy az összes klaszter belső heterogenitása (euklédeszi távolság alapján) a lehető legkisebb legyen az egész klaszterstruktúrára vetítve.

\section{ÚTELEMZÉS}

Az útelemzés (Structural Equation Modelling SEM) során a változó korrelációs összetevőkre bontása történik. Az út diagrammon a változók közötti utak mutatják, hogy a magyarázó változók - jelen esetben a megtakarítás / fó - hatása milyen úton jut el az eredmény változókig, jelen esteben a többi makrogazdasági változókig. Az útelemzés során arra is választ kapunk, hogy a változók között milyen erősségű parcionális, totális vagy indirekt kapcsolat található. Kutatásomban többek között arra kerestem a választ, hogy az építőipari vállalkozások árbevétele milyen hatást gyakorol a GDP-re, az inflációra és a munkanélküliségre.

A modellben az illeszkedések vizsgálatakor a következő illeszkedési teszteket/indexeket vizsgáltam:

\begin{tabular}{c|c}
\hline Illeszkedési mutató & Ajánlott érték \\
\hline RMSEA & $<0,06$ \\
\hline IFI & $>0,90$ \\
\hline NFI & $>0,90$ \\
\hline RFI & $>0,90$ \\
\hline TLI & $>0,90$ \\
\hline CFI & $>0,90$ \\
\hline
\end{tabular}

Forrás: Münnich, 2012 
- RMSEA (Root Mean Square Error of Approximation, Megközelítési négyzetes középérték),

- NFI (Normed Fit Index, Normalizált illeszkedési mutató),

- IFI (Incremental Fit Index, Inkrementális illeszkedési mutató),

- CFI (Comparative Fit Index, Összehasonlító illeszkedési mutató),

- RFI (Relative Fit Index, Relatív illeszkedési mutató),

- TLI (Tucker-Lewis Index).

\section{EREDMÉNYEK}

Az elemzés a hierarchikus eljárások közül a WARD-féle eljárás keretében került alkalmazásra, ami a gazdasági kutatásokban nemcsak rendkívül elterjedt, de az egyik nagy előnye, hogy a megfelelő klaszter felosztásokat eredményezi (Jánosa, 2015). A Ward-kritérium, egy olyan módszer, amelynél arra törekszünk, hogy az összes klaszter belső heterogenitása (eukléde- szi távolság alapján) a lehető legkisebb legyen az egész klaszterstruktúrára vetítve (Jánosa, 2015). Abból a feltételezésből indulok ki, hogy az adatbázisban a tagországok esetében kiugró vagy nagyon eltérő adatok nincsenek. A klaszterizálás eredményeképpen 6 csoportra tudtam bontani a 27 ország 19 vizsgált évét. A 2-es táblázatban az EU tagállamainak standardizált makrogazdasági adatai alapján létrejött klaszterstruktúra klaszterközéppontjai láthatóak.

Az elemzésben az interakciók számát szükséges volt alacsonyabb értékre állítani az alapértelmezett 10 interakciónál, hogy a csoportokban lévő mintaszám ne legyen alacsony. A klaszterképzést véglegesítve hat klasztercsoportot kaptunk. A 2-es táblázat tartalmazza a vizsgált tényezők klaszterközéppontjait, valamint a klasztercsoportokhoz rendelt évek számait (csoportok tagjainak száma). A klaszterek elnevezésénél a klaszterközéppontok nyújtottak segítséget.

Az első klasztercsoportot Mintaországnak neveztem el. A vizsgált csoportba kizárólag Lu-

2. táblázat: Az EU tagállamainak sztenderdizált makrogazdasági adatai alapján létrejött klaszterstruktúra klaszterközéppontjai

\begin{tabular}{c|c|c|c|c|c|c|c|c}
\hline $\begin{array}{c}\text { Gsopor- } \\
\text { tok tag- } \\
\text { jainak } \\
\text { száma }\end{array}$ & Infláció & $\begin{array}{c}\text { Mun- } \\
\text { kanél- } \\
\text { küliség }\end{array}$ & $\begin{array}{c}\text { Állam- } \\
\text { adós- } \\
\text { ság }\end{array}$ & $\begin{array}{c}\text { GDP } \\
\text { per } \\
\text { lakos- } \\
\text { ság }\end{array}$ & $\begin{array}{c}\text { EU } \\
\text { Büdzsé } \\
\text { per } \\
\text { lakos- } \\
\text { ság }\end{array}$ & $\begin{array}{c}\text { Állam- } \\
\text { adós- } \\
\text { ság }\end{array}$ & $\begin{array}{c}\text { Megta- } \\
\text { karítás } \\
\text { GDP }\end{array}$ & $\begin{array}{c}\text { Gsoportok be- } \\
\text { sorolása }\end{array}$ \\
\hline 46 & $-0,340$ & 2,344 & 0,349 & $-0,696$ & $-0,342$ & $-0,203$ & $-0,740$ & $\begin{array}{c}\text { Krízisben lévó } \\
\text { államok }\end{array}$ \\
\hline 159 & $-0,241$ & $-0,039$ & 0,926 & $-0,138$ & $-0,154$ & $-0,149$ & $-0,424$ & $\begin{array}{c}\text { Fejlődő, de } \\
\text { eladósodott } \\
\text { államok }\end{array}$ \\
\hline 135 & 0,087 & $-0,059$ & $-0,873$ & $-0,723$ & $-0,198$ & 0,112 & $-0,004$ & Fejlődó országok \\
\hline 120 & $-0,316$ & $-0,542$ & $-0,055$ & 0,916 & $-0,284$ & $-0,555$ & 0,622 & Jóléti államok \\
\hline 17 & $-0,139$ & $-0,917$ & $-1,342$ & 3,152 & 4,478 & 0,542 & 3,085 & Minta országok \\
\hline 28 & 2,467 & $-0,038$ & $-0,786$ & $-1,062$ & $-0,414$ & $-0,133$ & $-0,775$ & Lemaradók \\
\hline
\end{tabular}

Forrás: saját készités és számitás az EUROSTAT (Eurostat 2020.) adatai alapján 
xemburg tartozott, ahol az alacsony infláció mellé szintén alacsony munkanélküliség társul. Az államadóssági ráta ennél a csoportnál a legkisebb, míg a háztartások megtakarításai a legmagasabbak. Luxemburg esetében az EU-tól kapott támogatás egy főre eső értéke a legmagasabb a többi csoportéhoz képest.

A Mintaország után a második legjobb mutatókkal rendelkező csoport a jóléti államok voltak. A főleg nyugat-európai országokból álló csoport, az egyik legjobb gazdasági eredményekkel rendelkezik. A 6 csoportra vetítve, itt a legkisebb az inflációs ráta, illetve a második legalacsonyabb munkanélküliségi mutatóval rendelkezik. Magas GDP adatok mellé, magas megtakarítás és alacsony államadósság társul. Az elemzés a következő államokat sorolta a jóléti országok közé: Ausztria, Németország, Dánia, Finnország, Íroszág, Hollandia és Svédország.

A vizsgált mutatók alapján a felzárkózó országok közé kerültek azok az országok, amelyek alacsony államadósággal, közepes megtakarítással és alacsony inflációval jellemezhetőek. Ezeknél az országoknál a támogatás, valamint a GDP az adott ország létszámra vetítve alacsonynak jellemezhető. Itt helyezkednek el azok a Kelet-Európai országok, amelyek a 2000 években lettek az EU tagjai. A klaszterképzés eredményeképpen a következő országok kerültek a felzárkózó országok csoportjába: Belgium, Ciprus, Franciaország, Görögország, Magyarország, Olaszország, Portugália és Szlovénia.

A fejlödó, de eladósodott országokat rendszerint a következő közös jellemzők kötik össze: magas az államadósság mértéke, alacsony mértékủ a háztartások megtakarítása, közepes mértékű az infláció és magas a munkanélküliségi ráta. Annak ellenére, hogy az országok súlyosan eladósodottak, az egy fóre jutó GDP értéke magasnak értékelhető. A csoport EU-s támogatásának mértéke közepesnek tekinthető. Ennél a klasztercsoportnál a következő országok találhatóak: Portugália, Görögország, Szlovákia.

A krizisben lévő országcsoportot kedvezőtlen gazdasági mutatók jellemzik. A csoport tag- jait rossz munkanélküliségi mutató és magas államadósság jellemzi. A háztartások kevés megtakarítással rendelkeznek, valamint a GDP az adott ország létszámára vetítve a második legrosszabb értékeket éri el az Európai Unióban. A krízisben lévő tagállamok EU-s támogatásának mértéke közepesnek tekinthető. A klaszterképzés eredményeképpen a következő országok kerültek a csoportba: Bulgária, Csehország, Spanyolország, Litvánia, Lettország, Lengyelország, Szlovákia, Szlovénia.

Az utolsó klasztercsoportot lemaradóknak neveztem el. A csoportba kerülő országok gazdasági mutatói a legrosszabbak az Európai Unióban. Magas inflációs ráta mellett, az 1 före eső GDP adatok messze az EU átlag alatt helyezkednek el. Az ide sorolt országok háztartásai kevés megtakarítással, valamint magas államadóssággal rendelkeznek. A klaszterképzés eredményeképpen a következő országok kerültek a csoportba: Románia, Bulgária, Magyarország, Litvánia.

\section{A mikrovállalkozások és a tipizált tagországok oksági kapcsolatának bemutatása}

A KKV-szektor és a makrogazdasági mutatók oksági kapcsolatát az útelemzés (SEM) segítségével vizsgáltam. A nyilak az 5 változó (megtakarítás, GDP, infláció, munkanélküliség, építőipari kkv) közötti oksági kapcsolatot hivatottak jelezni. A megtakarítás kiindulópontjául szolgáló változó az ok, a nyíl végpontjában (GDP, infláció, munkanélküliség, építőipari kkv-k), az okozati változók találhatóak. Az általam vizsgált 5 manifeszt változó: megtakarítás, GDP, infláció, munkanélküliség, építőipari kkv-k árbevétele. A modellemben, a megtakarítás az egyetlen olyan változó, amelynek egyetlen másik (modellben szereplő) változó sem az okozója, ezt tehát kiinduló magyarázó változónak tekinthető, míg a modellben szereplő többi változó endogén (GDP, infláció, munkanélküliség, építőipari kkv-k árbevétele) változónak tekinthető. Az útelemzés során a változó korrelációs összetevőkre bontása történik. Az út diagramon a változók közötti utak mutatják, 


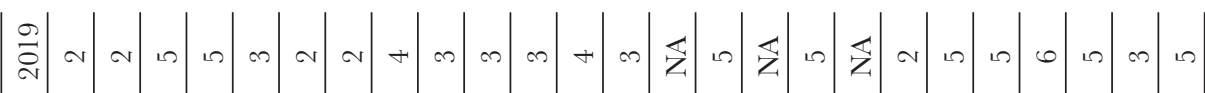

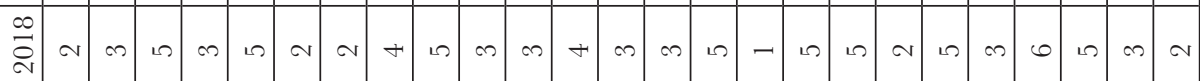

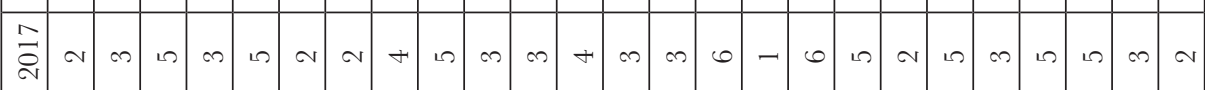

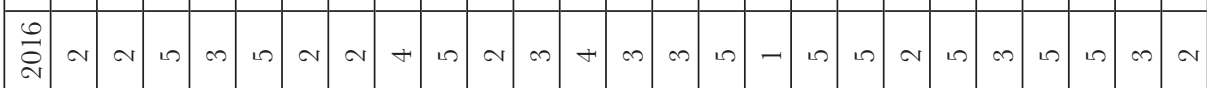

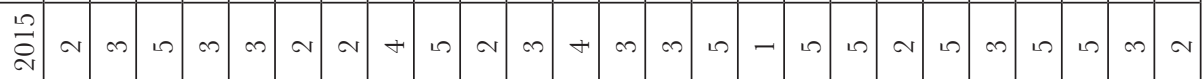

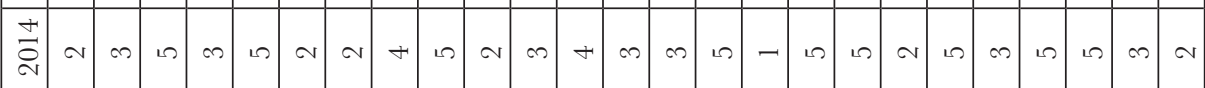

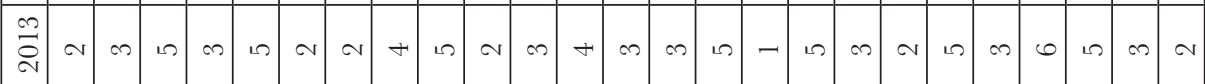

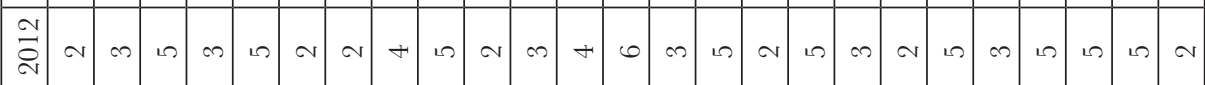

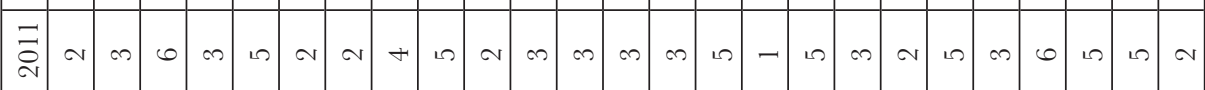

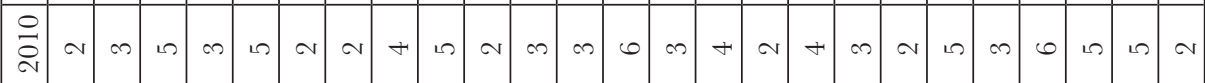

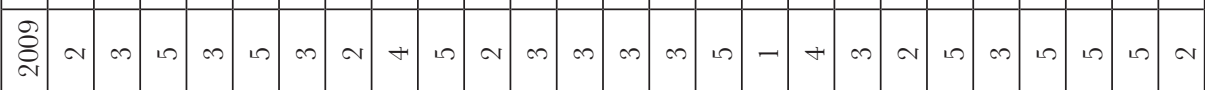

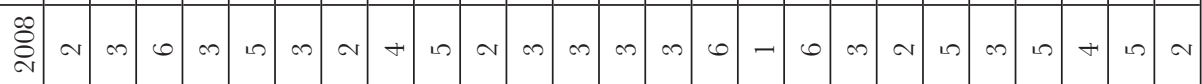

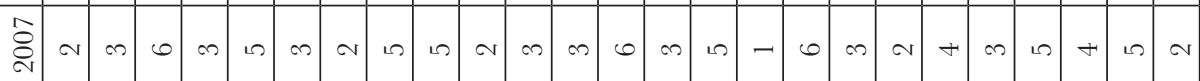

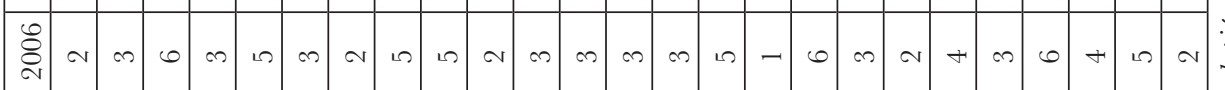

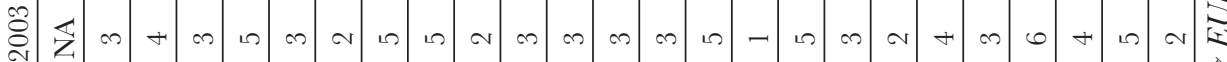

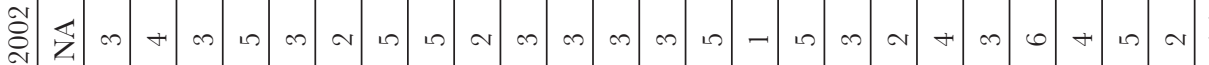
वें

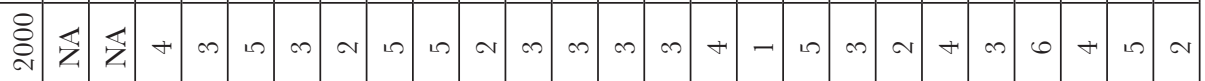

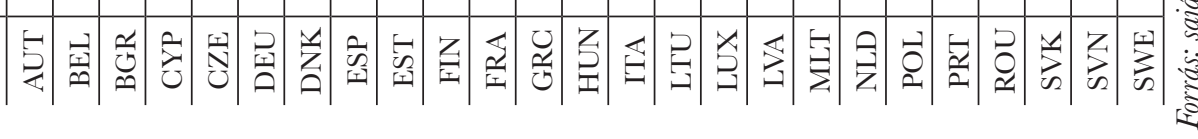


4. táblázat: Mutatók mértékegységének meghatározása

\begin{tabular}{c|c}
\hline Mutató megnevezése & Mértékegység meghatározása \\
\hline EU büdzsé per fó & euró per fó \\
\hline GDP arányos államadósság & százalékpont \\
\hline GDP per fó & euró per fó \\
\hline Infláció & százalékpont \\
\hline Építőipari KKV-k árbevétele & 1 lakosra jutó KKV árbevétel 1000 euróban \\
\hline Megtakarítás per fó & euró per fó \\
\hline Munkanélküliség & százalékpont \\
\hline
\end{tabular}

Forrás: saját szerkesztés

hogy a megtakarítás/fö milyen úton jut el a többi makrogazdasági változókig. Az útelemzés azt is megmutatja, hogy a változók között milyen erősségű parcionális, totális vagy indirekt kapcsolat található (Münnich, 2012). Kutatásomban többek között arra kerestem a választ, hogy az építőipari vállalkozások árbevétele hogyan hat a GDP-re, az inflációra és a munkanélküliségre.

Meghatároztam a makrogazdasági mutatók és az építőipari KKV-k mértékegységeit. Az EU büdzsét, a megtakarítást és a GDP-t euro/ főben határoztam meg a vizsgálat során. A kutatásba bevont tagországok esetében a további három mutatót az aktuális lakossági létszámmal osztottam, így az egységek meghatározása a következő módon alakult: egy főre jutó GDP, megtakarítás, valamint a EU-büdzsé.

A 5-ös táblázatban láthatók a kutatás eredményeként megkapott illeszkedési indexek. A TLI értéke a modellben 0,695, ez azért kisebb mint 0,9, mert maga a modell a nem szignifikáns kap- csolatokra érzékenyebb. Itt érdemes megjegyezni, hogy az illeszkedési index 0,9 alatti értéke az alacsony elemszámhoz is köthető. A makrogazdasági mutatók és az építőipari árbevétel közötti kapcsolatok nem minden esetben szignifikánsak.

Az 6-os táblázat részletezi a kapott eredményeket a Mintaország esetében. Ha az építőipari mikrovállalkozás 1 lakosra jutó árbevétele 1 millió euróval növekszik, akkor a munkanélküliségi ráta ez a változó 0,539 százalékponttal megnöveli. A mikrovállalkozások árbevételének emelkedése, a munkanélküliségi rátára negatív hatással van. Itt érdemes lenne további kutatásokat végezni arra vonatkozóan, hogy a mikrovállalkozások árbevételének emelkedése milyen tényezők miatt hat negatívan a munkanélküliségi rátára. A Mintaország esetében az is megállapítható, hogy ha az építőipari mikrovállalkozások 1 lakosra jutó árbevétele 1 millió euróval növekszik, akkor a GDP 7131 euro / fövel emelkedik.

Ameddig a mintaország megtakarítása nem

5. táblázat: A modell illeszkedésnek indexei

\begin{tabular}{c|c|c|c|c|c}
\hline \multirow{2}{*}{ Model } & NFI & RFI & IFI & TLI & \multirow{2}{*}{ GFI } \\
\cline { 2 - 5 } & Delta1 & rho1 & Delta2 & rho2 & \\
\hline Default model & 0,977 & 0,65 & 0,981 & 0,695 & 0,98 \\
\hline
\end{tabular}

Forrás: saját szerkesztés és számitás az Eurostat, Worldbank adatai alapján 
6. táblázat: Szignifikáns kapcsolatok mértéke a mintaországban

\begin{tabular}{|c|c|c|c|c|c|c|}
\hline \multicolumn{2}{|c|}{ Mintaország } & Becslés & St. hiba & G.R. & P \\
\hline Árbevétel_0_9 & $<---$ & Megtakarítás_per_k_fó & $-0,02$ & 0,078 & $-0,259$ & 0,795 \\
\hline GDP_per_k_fó & $<---$ & Árbevétel_0_9 & 7,131 & 0,268 & 26,641 & p $<0,001$ \\
\hline Munkanélküliség & $<---$ & Árbevétel_0_9 & 0,539 & 0,084 & 6,428 & p $<0,001$ \\
\hline GDP_per_k_fó & $<---$ & Megtakarítás_per_k_fó & 0,529 & 0,086 & 6,178 & p <0,001 \\
\hline Munkanélküliség & $<---$ & Megtakarítás_per_k_fó & 0,041 & 0,027 & 1,526 & 0,127 \\
\hline Infláció & $<---$ & Árbevétel_0_9 & $-0,13$ & 1,08 & $-0,121$ & 0,904 \\
\hline Infláció & $<---$ & Munkanélküliség & $-0,392$ & 0,234 & $-1,672$ & 0,095 \\
\hline Infláció & $<---$ & GDP_per_k_fó & 0,009 & 0,147 & 0,063 & 0,95 \\
\hline Infláció & $<---$ & Megtakarítás_per_k_fó & 0,06 & 0,083 & 0,715 & 0,475 \\
\hline
\end{tabular}

Forrás: saját szerkesztés és számitás az Eurostat, Worldbank adatai alapján

hatott az vállalkozások árbevételére, addig a jóléti államok esetében a megtakarítás 1 eurónyi növekedése 0,093 euró árbevétel növekedést generál az építőipari mikrovállalkozásoknál. A kutatás eredménye rámutat arra, hogy a munkanélküliségi ráta 2,328 egységgel csökken, ha az építőipari mikrovállalkozás árbevétele 1 millió euróval növekszik.

A felzárkózó államok esetében is pozitívan hat a megtakarítás növekedése a mikrovállalkozások árbevételének növekedésére. A megtakarítás 1 eurós növekedése 0,2 eurót generál a

7. táblázat: Szignifikáns kapcsolatok mértéke a jóléti államoknál

\begin{tabular}{c|c|c|c|c|c|c}
\hline \multicolumn{2}{c|}{ Jóléti államok } & Becslés & $\begin{array}{c}\text { St. } \\
\text { hiba }\end{array}$ & G.R. & P \\
\hline Árbevétel_0_9 & $<---$ & Megtakarítás_per_k_fó & 0,093 & 0,015 & 5,995 & $\mathrm{p}<0,001$ \\
\hline GDP_per_k_fó & $<---$ & Árbevétel_0_9 & 0,278 & 0,643 & 0,432 & 0,665 \\
\hline Munkanélküliség & $<---$ & Árbevétel_0_9 & 2,328 & 0,23 & 10,106 & $\mathrm{p}<0,001$ \\
\hline GDP_per_k_fó & $<---$ & Megtakarítás_per_k_fó & 1,978 & 0,108 & 18,369 & $\mathrm{p}<0,001$ \\
\hline Munkanélküliség & $<---$ & Megtakarítás_per_k_fó & $-0,414$ & 0,043 & $-9,73$ & $\mathrm{p}<0,001$ \\
\hline Infláció & $<---$ & Árbevétel_0_9 & $-0,186$ & 0,225 & $-0,027$ & 0,408 \\
\hline Infláció & $<---$ & Munkanélküliség & $-0,122$ & 0,058 & $-2,084$ & 0,037 \\
\hline Infláció & $<---$ & GDP_per_k_fó & $-0,042$ & 0,017 & $-2,552$ & 0,011 \\
\hline Infláció & $<----$ & Megtakarítás_per_k_fó & 0,038 & 0,048 & 0,787 & 0,431 \\
\hline
\end{tabular}

Forrás: saját szerkesztés és számitás az Eurostat, Worldbank adatai alapján 


\begin{tabular}{c|c|c|c|c|c|c}
\hline \multicolumn{2}{c|}{ Felzárkózó államok } & Becslés & $\begin{array}{c}\text { St. } \\
\text { hiba }\end{array}$ & G.R. & P \\
\hline Árbevétel_0_9 & $<---$ & Megtakarítás_per_k_fó & 0,2 & 0,066 & 3,024 & 0,002 \\
\hline GDP_per_k_fó & $<---$ & Árbevétel_0_9 & $-1,637$ & 1,052 & $-1,556$ & 0,12 \\
\hline Munkanélküliség & $<---$ & Árbevétel_0_9 & $-2,287$ & 1,236 & $-1,051$ & 0,064 \\
\hline GDP_per_k_fó & $<---$ & Megtakarítás_per_k_fó & 3,65 & 0,332 & 10,985 & p <0,001 \\
\hline Munkanélküliség & $<---$ & Megtakarítás_per_k_fó & 0,484 & 0,394 & 1,229 & 0,219 \\
\hline Infláció & $<---$ & Árbevétel_0_9 & 0,719 & 0,896 & 0,802 & 0,423 \\
\hline Infláció & $<---$ & Munkanélküliség & $-0,028$ & 0,098 & $-0,29$ & 0,772 \\
\hline Infláció & $<---$ & GDP_per_k_fó & $-0,458$ & 0,113 & $-4,044$ & p <0,001 \\
\hline Infláció & $<---$ & Megtakarítás_per_k_fó & 0,871 & 0,508 & 1,716 & 0,086 \\
\hline
\end{tabular}

Forrás: saját szerkesztés és számitás az Eurostat, Worldbank adatai alapján

mikrovállalkozások árbevételében.

A felzárkózó, de eladósodott klaszterek esetében, a megtakarítás $1 €$-s növekedése, 0,245 eurós árbevétel növekedést vált ki az építőipari mikrovállalkozásoknál.
A krízisben lévő országok esetében, a megtakarítás 0,01 euróval (0,235 euró) kisebb hatást fejt ki a mikrovállalkozások árbevételére, mint a felzárkózó, de eladósodott klaszterek esetében. A krízisben lévő klasztercsoport esetében

9. táblázat: Szignifikáns kapcsolatok mértéke a felzárkózó, de eladósodott államoknál

\begin{tabular}{l|l|l|c|c|c|c}
\hline \multicolumn{2}{c|}{ Felzárkózó, de eladósodott államok } & Becslés & $\begin{array}{c}\text { St. } \\
\text { hiba }\end{array}$ & G.R. & P \\
Árbevétel_0_9 & $<---$ & Megtakarítás_per_k_fó & 0,245 & 0,016 & 15,177 & p <0,001 \\
\hline GDP_per_k_fó & $<---$ & Árbevétel_0_9 & 0,868 & 1,609 & 0,54 & 0,589 \\
\hline Munkanélküliség & $<---$ & Árbevétel_0_9 & $-1,455$ & 1,341 & $-1,085$ & 0,278 \\
\hline GDP_per_k_fó & $<---$ & Megtakarítás_per_k_fó & 2,162 & 0,412 & 5,248 & p <0,001 \\
\hline Munkanélküliség & $<---$ & Megtakarítás_per_k_fó & $-0,168$ & 0,343 & $-0,488$ & 0,625 \\
\hline Infláció & $<---$ & Árbevétel_0_9 & 0,569 & 0,835 & 0,682 & 0,495 \\
\hline Infláció & $<---$ & Munkanélküliség & $-0,299$ & 0,076 & $-3,94$ & p <0,001 \\
\hline Infláció & $<---$ & GDP_per_k_fó & $-0,007$ & 0,063 & $-0,106$ & 0,916 \\
\hline Infláció & $<---$ & Megtakarítás_per_k_fó & $-0,306$ & 0,242 & $-1,263$ & 0,207 \\
\hline
\end{tabular}

Forrás: saját szerkesztés és számitás az Eurostat, Worldbank adatai alapján 


\begin{tabular}{l|c|l|c|c|c|c}
\hline \multicolumn{2}{c|}{ Krízisben lévő országok } & Becslés & $\begin{array}{c}\text { St. } \\
\text { hiba }\end{array}$ & C.R. & P \\
\hline Árbevétel_0_9 & $<---$ & Megtakarítás_per_k_fó & 0,235 & 0,016 & 15,036 & $\mathrm{p}<0,001$ \\
\hline GDP_per_k_fó & $<---$ & Árbevétel_0_9 & 2,946 & 0,848 & 3,473 & $\mathrm{p}<0,001$ \\
\hline Munkanélküliség & $<---$ & Árbevétel_0_9 & $-2,768$ & 0,893 & $-3,099$ & 0,002 \\
\hline GDP_per_k_fő & $<---$ & Megtakarítás_per_k_fő & 1,65 & 0,227 & 7,285 & $\mathrm{p}<0,001$ \\
\hline Munkanélküliség & $<---$ & Megtakarítás_per_k_fó & $-0,117$ & 0,238 & $-0,491$ & 0,624 \\
\hline Infláció & $<---$ & Árbevétel_0_9 & 1,832 & 0,702 & 2,611 & 0,009 \\
\hline Infláció & $<---$ & Munkanélküliség & $-0,22$ & 0,055 & $-3,976$ & $\mathrm{p}<0,001$ \\
\hline Infláció & $<---$ & GDP_per_k_fó & $-0,251$ & 0,059 & $-4,28$ & $\mathrm{p}<0,001$ \\
\hline Infláció & $<---$ & Megtakarítás_per_k_fő & $-0,155$ & 0,178 & $-0,873$ & 0,382 \\
\hline
\end{tabular}

Forrás: saját szerkesztés és számitás az Eurostat, Worldbank adatai alapján

elmondható, hogy az 1000 főre eső GDP-t nélküliségi ráta és az infláció tekintetében. A 2,946 euróval emeli meg, ha az építőipari munkanélküliségi rátát 2,768 százalékponttal, mikrovállalkozások 1 főre eső árbevétele 1 az inflációt pedig 2,768 százalékponttal millió euróval növekszik. Szintén szignifikáns csökkenti, ha az építőipari mikrovállalkozások kapcsolat került megállapításra a munka- 1 főre eső árbevétele 1 millió euróval növekszik.

11. táblázat: Szignifikáns kapcsolatok mértéke a lemaradó országoknál

\begin{tabular}{|c|c|c|c|c|c|c|}
\hline \multicolumn{3}{|c|}{ Lemaradó országok } & \multirow{2}{*}{$\begin{array}{c}\text { Becslés } \\
0,213\end{array}$} & \multirow{2}{*}{$\begin{array}{c}\begin{array}{c}\text { St. } \\
\text { hiba }\end{array} \\
0,032\end{array}$} & \multirow{2}{*}{$\begin{array}{c}\text { C.R. } \\
6,55\end{array}$} & \multirow{2}{*}{$\begin{array}{c}\mathbf{P} \\
p<0,001\end{array}$} \\
\hline Árbevétel_0_9 & $<---$ & Megtakarítás_per_k_fő & & & & \\
\hline GDP_per_k_fö & $<---$ & Árbevétel_0_9 & $-1,651$ & 0,936 & $-1,764$ & 0,078 \\
\hline Munkanélküliség & $<---$ & Árbevétel_0_9 & $-4,313$ & 2,045 & $-2,109$ & 0,035 \\
\hline GDP_per_k_fo" & $<---$ & Megtakarítás_per_k_fö & 3,955 & 0,261 & 15,167 & $\mathrm{p}<0,001$ \\
\hline Munkanélküliség & $<---$ & Megtakarítás_per_k_fó & 0,938 & 0,57 & 1,645 & 0,1 \\
\hline Infláció & $<---$ & Árbevétel_0_9 & 28,368 & 2,947 & 9,625 & $\mathrm{p}<0,001$ \\
\hline Infláció & $<--$ & Munkanélküliség & 0,129 & 0,225 & 0,572 & 0,568 \\
\hline Infláció & $<---$ & GDP_per_k_fö & $-0,159$ & 0,491 & $-0,323$ & 0,746 \\
\hline Infláció & $<---$ & Megtakarítás_per_k_fő & $-8,46$ & 2,095 & $-4,039$ & $\mathrm{p}<0,001$ \\
\hline
\end{tabular}

Forrás: saját szerkesztés és számitás az Eurostat, Worldbank adatai alapján 


\section{Tudományos mühely}

1. ábra: A megtakaritás hatása az épitóipari mikrovállalkozások árbevételére

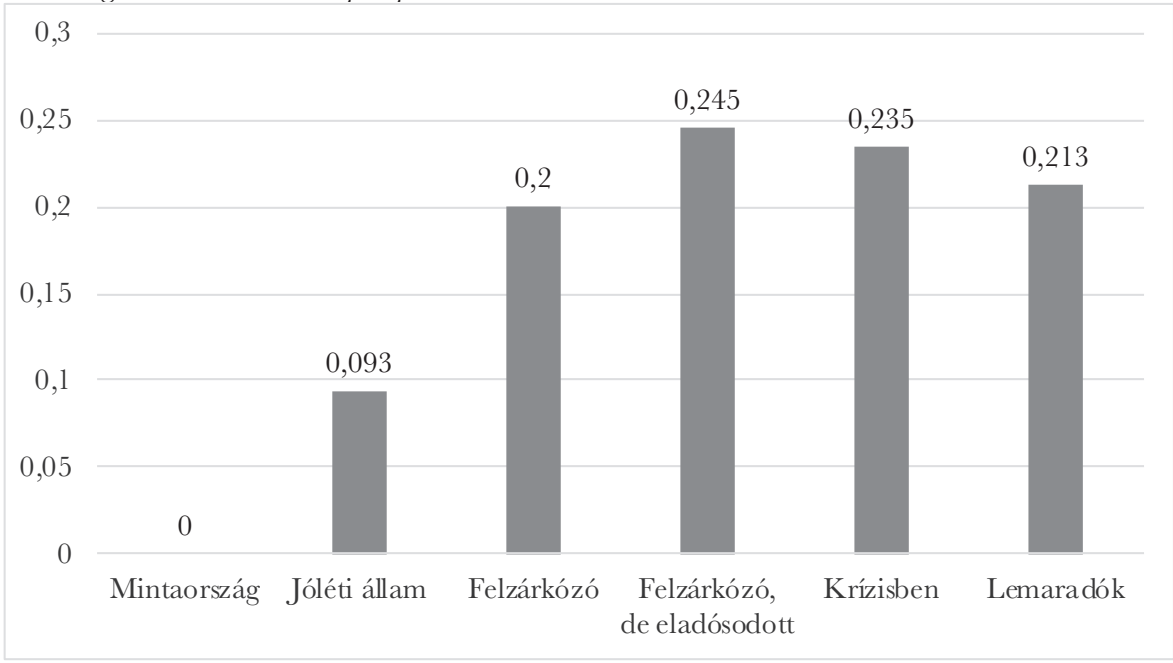

Forrás: saját szerkesztés és számitás az Eurostat, Worldbank adatai alapján

A lemaradó államok esetében egy érdekes eredmény született, miszerint az építőipari mikrovállalkozások árbevételének növekedése az inflációs ráta $(39,851)$ növekedéséért felelős.

\section{KÖVETKEZTETÉSEK}

Az empirikus kutatásban két fő kérdést helyeztem a középpontba: a megtakarítás milyen hatást vált ki az építőipari mikrovállalkozások

2. ábra: Az épitöipari mikrovállalkozások hatása a GDP-re

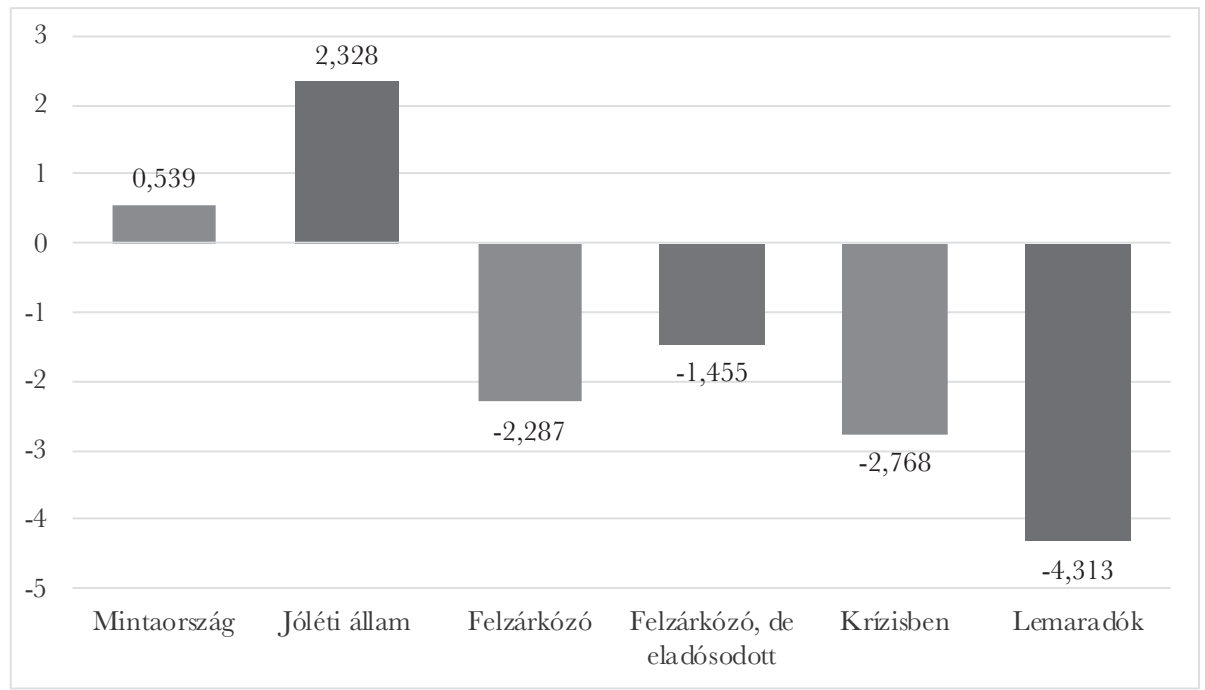

Forrás: saját szerkesztés és számitás az Eurostat, Worldbank adatai alapján 


\section{3. ábra: Az épitôipari mikrovállalkozások hatása a munkanélküliségre}

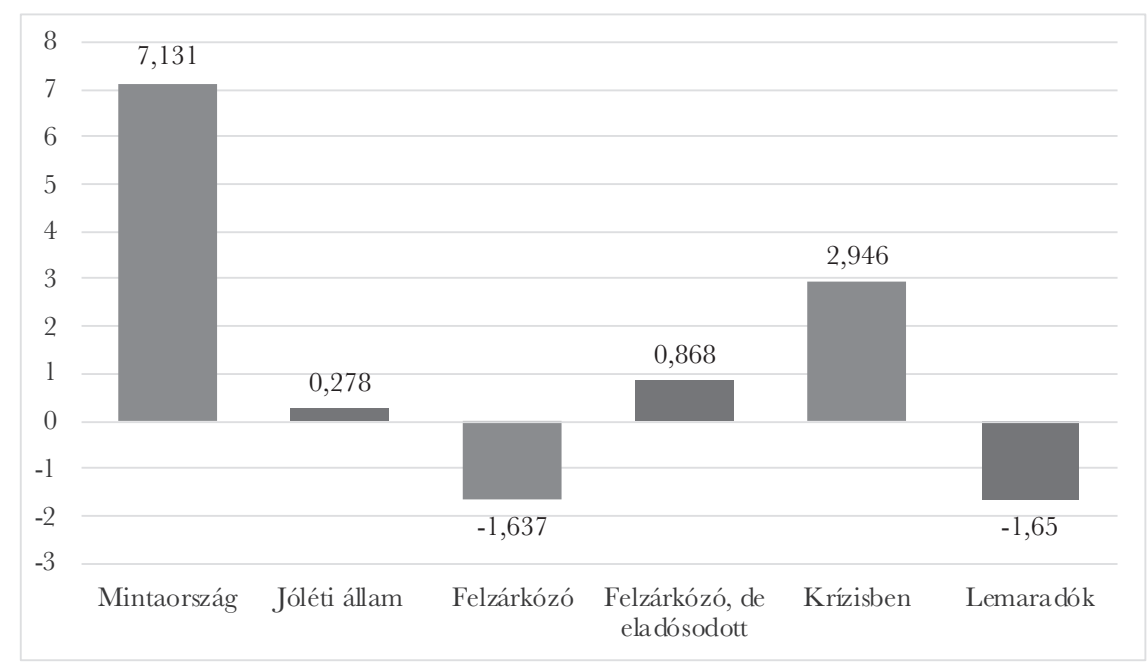

Forrás: saját szerkesztés és számitás az Eurostat, Worldbank adatai alapján

árbevételében, valamint az építőipari mikrovállalatok árbevételének 1 egységnyi növekedése milyen indirekt hatással van az adott klasztercsoportok makrogazdasági mutatóira.

A 1. ábrán látható, hogy a megtakarításnak mekkora árbevétel generáló ereje van a 6 klasztercsoportban. A „mintaország” kivételével, az összes klasztercsoportban az eredmények szignifikáns kapcsolatot mutattak. A kapott eredmények alapján megállapítható, hogy a megtakaritás pozitív árbevétel növelő hatása a luxemburgi mikrovállalkozásokon kívül minden más európai kisvállalkozásnál kimutatható. A kutatás rámutat, hogy a 2004 után csatlakozott tagországok esetében a megtakarítás növekedése 245\%-kal nagyobb hatást fejt ki az építőipari mikrovállalkozások árbevételének növekedésében, mint a jóléti államok esetében.

Az építőipari mikrovállalkozások hatása a GDP-re nem minden esetben nyert igazolást. Az eredmények alapján a 6 klasztercsoportból 3 esetében volt kimutatható szignifikáns kapcsolat. Azaz, az építőipari mikrovállalkozások árbevételének növekedése nem minden klaszterben generálja a GDP növekedést. A 2-es ábra alapján Luxemburgnak az 1 före eső GDP-jére van a legerőteljesebb hatása az építőipari mikrovállalkozások árbevételének növekedése. Ebben az esetben, ha az építőipari mikrovállalkozás árbevétele 1 millió euróval növekedett, akkor 7,131 euróval növeli az 1000 főre eső GDP-t. A felzárkózó (közép-európai országok többsége) és a krízisben (kelet-európai országok) lévő országok esetében is közel 3,8 euróval és 2,9 euróval növeli az 1000 főre eső GDP értékét.

Az 3-as ábrán mutatom be az építőipari mikrovállalkozások és a munkanélküliség esetében kapott eredményeket. A felzárkózó, de eladósodott klaszteren kívül, az összes további csoportnál szignifikáns kapcsolatot kaptunk. Az eredmények tekintetében kijelenthető, hogy az építőipari mikrovállalkozások árbevételének 1 millió euróval történő növekedése negatív hatással van a mintaországra, valamint a jóléti államokra. Ezek esetében a munkanélküliség 0,539 ponttal és 2,328 ponttal növekedett. A felzárkózó országok, a krízisben lévő országok és a lemaradók esetében is csökkenti a munkanélküliséget, ha az építőipari mikrovállalkozások 1 lakosra jutó árbevétele 1 millió euróval 
növekszik.

A tanulmány első részében a szegmenshez tartozó szakirodalmat tekintettem át, amely során az építőipari KKV-k és az építőipar klaszterek lehetséges stratégiájának fejlesztésére kaptunk megoldásokat. Az eredményeket öszszefoglalva, megállapíthatjuk, hogy az építőipari kisvállalkozások árbevételének hatása az elmaradott európai tagországok makrogazdasági mutatóira jelentősebbnek tekinthetők. Tekintve, hogy a téma specifikussága miatt szinte alig van elérhető forrás a témában, így az eredmények elméleti szinten értelmezhetőek, mivel összehasonlításukra jelen kutatásban nem volt lehetőségem.

\section{FELHASZNÁLT IRODALOM}

Bajmóczi Zoltán - Buzás Norbert - Gonda Rudolf Patik Réka - Szél Adrián (2002): Épitôipari klaszter - Esettanulmányok. A hazai épitóipar versenyképességének javitása Győr: Régió Art Kiadó. 125 - 168.

Barsi Boglárka (2002): Az épitóipar helyzete az EU csatlakozás után. A hazai épitöipar versenyképességének javitása: Klaszetrek szerepe a gazdaságfejlesztésben. Győr Régió Art Kiadó. 63-72.

Bencsik Andrea - Filep Bálint (2020): Relationship Between Knowledge Management and Innovation. Disruptive Technology: Concepts, Methodologies, Tools, and Applications, edited by Information Resources Management Association, IGI Global, pp. 531-554. http://doi:10.4018/9781-5225-9273-0.ch026

Bite Pál - Konczosné Szombathelyi Mária -Vasa László (2020): The Concept of Labour Migration from the Perspective of Central and Eastern Europe. Economics and Sociology 13:1 pp. 197-216. , 20 p. (2020) https://doi.org/10.14254/2071-789X.2020/13-1/13

Buzás Norbert - Kállay László - Lengyel Imre (2003.): Kis- és középvállalkozások a változó gazdaságban. https://eco.u-szeged.hu/kutatas-tudomany/tudomanyos-kozlemenyek/kis-kozepvallalkozasok-gazdasagban 2020.10.05. 108-112.

Csath Magdolna (2015): Rendszerváltás a gazdaságban, avagy hogyan tûnt el a magyar ipar? Kairosz Kiadó, Budapest, 160-166.

Danisch Goverment (1999): Structural Monitoring - International Benschmarking of Denmarkt. Koppenhága: Danisch Goverment.

Európai Bizottság (2012): Az uniós épitóipar és az abban mü- ködö vállalkozások fenntartható versenyképességi stratégiája . Európai Unió. Brüsszel

European Commission (2015a): http://ec.europa.eu/ growth/smes/cosme/ index_en.htm, 2021.06.28.

European Commission (2020): http://ec.europa.eu/ growth/smes/promoting-entrepreneurship/ index_ en.htm, 2021. 06. 28.

Eurpean Commission (2020) https://ec.europa.eu/commission/presscorner/detail/en/ MEMO_13_1152 7-8.

Eurostat (2020): Presse Portal Eurostat: https://www.presseportal.de/pm/ 121298/3793963 2020.10.07.

Európai Parlament (2020): https://www.europarl.europa.eu/factsheets/hu/sheet/ 63/a-kis-es-kozepvallalkozasok, 2020.10.07.

Eurostat yearbook (2010): Europa in figures https:// ec.europa.eu/eurostat/web/products-statistical-books/-/ks-cd-10-220, 2020.10.08.

Hertog, P. - Sinderen, J. - Roelandt , T. - Hove, N. (1999): Cluster Analysis and Cluster Policy in the Netherlands. Boosting Innovation. Paris: OECD.

Jánosa András (2015): Adatelemzés IBM SPSS Statsitics megoldások alkalmazásával. Budapest: Magyar Könyvvizsgálói Kamara Oktatási Központ Kft. 210-212.

Lengyel Imre - Rechnitzer János (2002): A hazai épitôipar versenyképességének javitása: Klaszterek szerepe a gazdaságfejlesztésben. Győr, Magyarország: Régió Art Kiadó.

Lentner Csaba - Vasa László - Hegedűs Szilárd (2020): The Assessment of Financial Risks of Municipally Owned Public Utility Companies in Hungary Between 2009 and 2018. Montenegrin Fournal of Economics 16 : 4 pp. 29-41.,

Losoncz Miklós (2019): Az uniós keretfeltételek és a kis-és középvállalkozások nemzetköziesedésének néhány kérdése. https://uni-bge.hu/Kutatasi-tevekenyseg/dokumentumok/Prosperitas/2019_2/Loconcz.pdf 1-6.p.

Münnich Ákos (2012): Strukturális egyneletek modellje, Debrecen, Kiadó: Debreceni Egyetem, 77-102.

OECD (2002):Clusters transition economies- progress, https://www.oecd.org/cfe/leed/ 2089148.pdf

Röhl, K. (2017): Europäische Mittelstandspolitik. Forschungsberichte aus dem Institut der deutschen Wirtschaft Köln: https://www.iwkoeln.de/fileadmin/publikationen/ 2017/344566/IW-Analyse_116_2017_Europaeische_Mittelstandspolitik.pdf

Vasa László (2010): Experiences of the CEE countries on overcoming of the world economic crisis. In: Abishev, A (szerk.) 5th Annual International Scientific Forum "Ryskulov Readings" Alma-Ata, Kazakhstan: Ekonomika Baspasy, pp. 37-52. 